\title{
DIFFERENCES IN PROKARYOTIC SPECIES BETWEEN PRIMARY AND LOGGED-OVER DEEP PEAT FOREST IN SARAWAK, MALAYSIA
}

\author{
MOHD SHAWAL THAKIB MAIDIN*; SAKINAH SAFARI*; NUR AZIEMAH GHANI*; SHARIFAH AZURA \\ SYED IBRAHIM*; SHAMSILAWANI AHAMED BAKERI*; MOHAMED MAZMIRA MOHD MASRI* and \\ SITI RAMLAH AHMAD ALI*
}

\begin{abstract}
Peatland has an important role in environmental sustainability which can be used for agricultural purposes. However, deforestation in the logged-over forest may disrupt the diversity of microbial population in peat soil. Therefore, this study focuses on the differences of microbial populations in Maludam primary forest and Cermat Ceria logged-over forest in Sarawak, Malaysia. The prokaryotic $16 S$ rDNA region was amplified followed by denaturing gradient gel electrophoresis (16S PCR-DGGE) analysis. Berger-Parker and Shannon-Weaver Biodiversity Index showed that Maludam $(0.11,7.75)$ was more diverse compared to Cermat Ceria $(0.19,7.63)$. Sequence analysis showed that the bacterial community in Maludam and Cermat Ceria were dominated by unclassified bacteria, followed by Acidobacteria, Actinobacteria, Firmicutes and $\alpha$-Proteobacteria. Based on the findings, the distinct species that can be found in Maludam were Acidobacterium capsulatum, Solibacter sp., Mycobacterium intracellulare, Rhodoplanes sp., Clostridia bacterium, Exiguobacterium sp. and Lysinibacillus fusiformis. While, the distinct species that can be found in Cermat Ceria were Telmatobacter, Mycobacterium tuberculosis and Bacillus tequilensis. Overall, the findings showed that microbial population in the logged-over forest are less diverse compared to primary forest. Higher prokaryotic diversity identified in the primary forest compared to logged-over forest showed that deforestation might cause prokaryotic population changes to both ecosystems.
\end{abstract}

Keywords: microbial diversity, deep peat, primary forest, logged-over forest.

Date received: 26 February 2016; Sent for revision: 4 March 2016; Received in final form: 9 May 2016; Accepted: 13 July 2016.

\section{INTRODUCTION}

Peatlands are formed by the accumulation and anaerobic processes of incomplete plant decay in water logged area for over hundreds of years (Cole et al., 2015). Around 50\%-70\% of wetlands are covered by the peatlands worldwide (Mishra et al., 2013). Still, it remains a major source of world's soil carbon at approximately one-third around the

Malaysian Palm Oil Board, 6 Persiaran Institusi,

Bandar Baru Bangi, 43000 Kajang, Selangor, Malaysia.

E-mail: ramlah@mpob.gov.my globe (Freeman et al., 2012). Tropical peatlands in South-east Asia is covered with $77 \%$ total carbon pool which is nearly 25 million hectares of land area (Page et al., 2011). Page et al. (2011) also stated that the density of carbon is higher in tropical peatlands compared to boreal or temperate peatlands. This is due to the deeper peat layers up to $20 \mathrm{~m}$ thickness compared to the other two peatlands.

The nutrient recycling, organic matter dynamics and decomposition processes in the soil are highly influenced by the microbial community that makes the ecosystem works perfectly (Talbot et al., 2014). Furthermore, the availability of nutrients from the 
decomposition and rhizodeposition processes also offer a great influence to the prokaryotic community in the soil(Trivedietal., 2013). Environmental changes and nutrient distribution due to the land conversion can contribute to the abundance and diversification of the bacterial communities (Baldrian et al., 2012). Other variable aspects such as soil moisture and temperature were identified to regulate the microbial diversity in a particular soil ecosystem (Lauber et al., 2013). These features determine the availability of the peatland as growing media, biota habitat, biodiversity and hydrotopography. The information gained from the microbial diversity evaluation is also crucial for plant pathogen and beneficial microbes detection for agricultural purposes. Thus, good land management practice can effectively control the microbial ecosystem in the agricultural soil. Conversely, the structure of the below ground ecosystems can be badly deteriorated due to the depletion of the soil carbon and biodiversity loss if poorly managed (Lauber et al., 2013).

Development of polymerase chain reactiondenaturing gradient gel electrophoresis (PCRDGGE) technique gives the opportunity to unravel the population dynamics of the culture independent bacterial species living in the soil (Zhang et al., 2014). This technique basically utilised by screening the bacterial fingerprint through molecular approach on the DGGE that enables the separation of different DNA sequences that have indistinguishable band length in the selected sampling site (Piterina and Pembroke, 2013). This fingerprint can be compared through numerous analysis tools such as cluster analysis, non-metric multidimensional scaling, visual inspection and moving window analysis that will directly bring the data into quantitative and qualitative biodiversity indices (Gomez-Balderas et al., 2014). Furthermore, almost $95 \%-99 \%$ of the bacterial community can be detected and potentially to be utilised as a genetic marker (Piterina and Pembroke, 2013).

The evolution of microbial populations in the soil is directly dependent on the structural features and physico-chemical changes that occurred in the ecosystem (Menezes-Oliveira et al., 2014) that can be analysed through PCR-DGGE technique. Therefore, this study was conducted to investigate the effect of logging on the prokaryotic population in the primary deep peat forest in Sarawak where microbial biodiversity in Maludam primary deep peat forest was compared to Cermat Ceria logged-over forest. The application of DNA fingerprinting methods enables the detection of diverse members of soil bacterial communities, including the unculturable microbes. The PCR coupled with DGGE has been used as culture-independent methods to determine species richness and differences of microbial communities between the primary and logged-over forest for this study.

\section{MATERIALS AND METHODS}

\section{Peat Soil Sampling}

Two peat areas consisting of deep peatland forest and logged-over forest at Sri Aman, Sarawak were selected as shown in Table 1. Maludam National Park and Cermat Ceria are primary and loggedover forest, respectively. Sampling of peat soil was taken from 10 GPS points in triplicates. The GPS points in Maludam were divided by two transects. The first transect consisted of point 1 until point 6 while the second transect consisted of point 7 until point 10 . The distance between each GPS point was separated approximately $10 \mathrm{~m}$ on average except for points 6 and 7 which were separated by $100 \mathrm{~m}$ apart (Figure 1a). The GPS points at Cermat Cermat were separated approximately $100 \mathrm{~m}$ apart (Figure $1 b$ ). A total of $25 \mathrm{~g}$ of soil samples were taken in 50 $\mathrm{ml}$ falcon tube in each coordinate at a depth of 0-30 $\mathrm{cm}$, midway between topsoil and water table. The samples were chilled and stored at $10^{\circ} \mathrm{C}$ prior to DNA extraction.

\section{DNA Extraction}

Total DNA was extracted from peat soil samples using GeneMATRIX Soil DNA Purification Kit (Eurx Ltd, Gdansk, Poland). The concentration and quality of DNA were measured using a Nanophotometer ${ }^{\mathrm{TM}}$ P360 (Implen GmbH, Schatzbogen, Germany) with minimum concentration and purity of $10 \mathrm{ng} \mu \mathrm{l}^{-1}$ and OD260/280 of 1.7-2.0, respectively. The extracted DNA was stored at $-20^{\circ} \mathrm{C}$ prior to analysis.

\section{PCR-DGGE Analysis}

PCR amplifications of the V3-V5 region (550 $\mathrm{bp)}$ of the $16 S \mathrm{rRNA}$ gene were performed with universal bacterial primers 341F-GC clamp (5'-cgcccg-ccg-cgc-gcg-gcg-ggc-ggg-gcg-ggg-gca-cgg-ggggcc-tac-gg-agg-cag-cag-3') and 907R (5'-ccc-cgt-caattc-att-tga-gtt-t-3') using the PCR program (Muyzer et al., 1997; Overmann and Tuschak, 1997). The PCR was performed in $25 \mathrm{ul}$ of reaction volume with a thermocycler (gradient) containing succession of 10 pmol of each primer, $100 \mathrm{mM}$ dNTPs, 1X PCR buffer, $50 \mathrm{mM} \mathrm{Mg} \mathrm{Cl}_{2}, 0.3 \%$ BSA and 2.5 units of Taq polymerase. The PCR started with initial denaturation at $94^{\circ} \mathrm{C}$ for $2 \mathrm{~min}, 35$ cycles of $94^{\circ} \mathrm{C}$ for $30 \mathrm{~s}, 52^{\circ} \mathrm{C}$ for $30 \mathrm{~s}$ and $72^{\circ} \mathrm{C}$ for $30 \mathrm{~s}$, final extension at $72^{\circ} \mathrm{C}$ for $2 \mathrm{~min}$ and held at $10^{\circ} \mathrm{C}$. Then the PCR products were subsequently subjected to DGGE analysis.

DGGE was performed using a D-code DGGE system (Bio-Rad, USA). The gradient of denaturants and running conditions were optimised as follows: $40 \mu \mathrm{l}$ of GC clamped-amplicons were resolved in $6 \%$ acrylamide (37.5:1, acrylamide:Bis-acrylamide) 
TABLE 1. LOCATION OF SAMPLING POINTS STUDIED IN DEEP PEAT SARAWAK, MALAYSIA

\begin{tabular}{|c|c|c|c|}
\hline No. & Estates & $\begin{array}{c}\text { Sampling } \\
\text { points }\end{array}$ & Location on GPS \\
\hline \multirow[t]{11}{*}{1} & Maludam National Park & & \\
\hline & & 1 & $\mathrm{~N}, 1^{\circ} 37^{\prime} 43.15897^{\prime \prime} \mathrm{E}, 111^{\circ} 02^{\prime} 22.12806^{\prime \prime}$ \\
\hline & & 2 & $\mathrm{~N}, 1^{\circ} 37^{\prime} 43.14684^{\prime \prime} \mathrm{E}, 111^{\circ} 02^{\prime} 22.10784^{\prime \prime}$ \\
\hline & & 3 & $\mathrm{~N}, 1^{\circ} 37^{\prime} 43.13676^{\prime \prime} \mathrm{E}, 111^{\circ} 02^{\prime} 22.10172^{\prime \prime}$ \\
\hline & & 4 & $\mathrm{~N}, 1^{\circ} 37^{\prime} 43.11048^{\prime \prime} \mathrm{E}, 111^{\circ} 02^{\prime} 22.09380^{\prime \prime}$ \\
\hline & & 5 & $\mathrm{~N}, 1^{\circ} 37^{\prime} 43.09068^{\prime \prime} \mathrm{E}, 111^{\circ} 02^{\prime} 22.08912^{\prime \prime}$ \\
\hline & & 6 & $\mathrm{~N}, 1^{\circ} 37^{\prime} 43.08420^{\prime \prime} \mathrm{E}, 111^{\circ} 02^{\prime} 22.08408^{\prime \prime}$ \\
\hline & & 7 & $\mathrm{~N}, 1^{\circ} 37^{\prime} 47.89410^{\prime \prime} \mathrm{E}, 111^{\circ} 02^{\prime} 23.28638^{\prime \prime}$ \\
\hline & & 8 & $\mathrm{~N}, 1^{\circ} 37^{\prime} 48.31230^{\prime \prime} \mathrm{E}, 111^{\circ} 02^{\prime} 22.79459^{\prime \prime}$ \\
\hline & & 9 & $\mathrm{~N}, 1^{\circ} 37^{\prime} 48.40347^{\prime \prime} \mathrm{E}, 111^{\circ} 02^{\prime} 22.83173^{\prime \prime}$ \\
\hline & & 10 & $\mathrm{~N}, 1^{\circ} 37^{\prime} 48.52168^{\prime \prime} \mathrm{E}, 111^{\circ} 02^{\prime} 22.79459^{\prime \prime}$ \\
\hline \multirow[t]{11}{*}{2} & Cermat Ceria logged-over forest & & \\
\hline & & 1 & $\mathrm{~N}, 1^{\circ} 23^{\prime} 58.85626^{\prime \prime} \mathrm{E}, 111^{\circ} 24^{\prime} 08.61675^{\prime \prime}$ \\
\hline & & 2 & $\mathrm{~N}, 1^{\circ} 23^{\prime} 58.29805^{\prime \prime} \mathrm{E}, 111^{\circ} 24^{\prime} 08.52634^{\prime \prime}$ \\
\hline & & 3 & $\mathrm{~N}, 1^{\circ} 23^{\prime} 57.46257^{\prime \prime} \mathrm{E}, 111^{\circ} 24^{\prime} 13.68159^{\prime \prime}$ \\
\hline & & 4 & $\mathrm{~N}, 1^{\circ} 23^{\prime} 56.50727^{\prime \prime} \mathrm{E}, 111^{\circ} 24^{\prime} 17.37404^{\prime \prime}$ \\
\hline & & 5 & $\mathrm{~N}, 1^{\circ} 23^{\prime} 56.11111^{\prime \prime} \mathrm{E}, 111^{\circ} 24^{\prime} 21.85227^{\prime \prime}$ \\
\hline & & 6 & $\mathrm{~N}, 1^{\circ} 23^{\prime} 55.39797^{\prime \prime} \mathrm{E}, 111^{\circ} 24^{\prime} 27.35565^{\prime \prime}$ \\
\hline & & 7 & $\mathrm{~N}, 1^{\circ} 23^{\prime} 54.86120^{\prime \prime} \mathrm{E}, 111^{\circ} 24^{\prime} 31.39397^{\prime \prime}$ \\
\hline & & 8 & $\mathrm{~N}, 1^{\circ} 23^{\prime} 52.45833^{\prime \prime} \mathrm{E}, 111^{\circ} 24^{\prime} 39.79472^{\prime \prime}$ \\
\hline & & 9 & $\mathrm{~N}, 1^{\circ} 23^{\prime} 42.87224^{\prime \prime} \mathrm{E}, 111^{\circ} 24^{\prime} 41.60620^{\prime \prime}$ \\
\hline & & 10 & $\mathrm{~N}, 1^{\circ} 23^{\prime} 53.80569^{\prime \prime} \mathrm{E}, 111^{\circ} 24^{\prime} 43.18166^{\prime \prime}$ \\
\hline
\end{tabular}

TABLE 2. MICROBIAL BIODIVERSITY INDICES FOR TOTAL MICROBES ON PEAT SOIL SAMPLED FROM LOGGED-OVER AND PRIMARY PEAT FOREST

\begin{tabular}{|c|c|c|c|}
\hline \multicolumn{2}{|c|}{ Shannon-Weaver biodiversity index } & \multicolumn{2}{|c|}{ Berger-Parker dominance index } \\
\hline Maludam & Cermat Ceria & Maludam & Cermat Ceria \\
\hline 7.747788 & 7.62656 & 0.11 & 0.19 \\
\hline
\end{tabular}

perpendicular gels in a $40 \%-70 \%$ gradient of denaturants (where $100 \%$ denaturant concentration) was equal to $7 \mathrm{M}$ urea (Sigma, USA) and $40 \%$ (v/v) of deionised formamide (Amresco ${ }^{\circledR}$ Solon Ind., Ohio, USA). TEMED and ammonium persulfate were added to a final concentration of $0.1 \%$ each. Each gel was loaded with 100 bp marker (Invitrogen, USA) as reference lane. Electrophoresis was run in 1X TAE buffer ( $40 \mathrm{mM}$ Tris-acetate, $1 \mathrm{mM}$ EDTA pH 8.0 ) at constant $65 \mathrm{~V}$ for $17 \mathrm{hr}$ and at $60^{\circ} \mathrm{C}$ using the Bio-Rad D-Code ${ }^{\mathrm{TM}}$ Universal Mutation Detection System. Gels were stained with $0.1 \%$ (v/v) SYBR gel stain and visualised under UV using AlphaImager HP (Alpha Innotech, San Leandro, CA).

\section{Band Matching Analysis of PCR-DGGE Profiles}

PCR-DGGE patterns were analysed using Phoretix 1D Gel Analysis software (Total Lab
Quant Ltd, United Kingdom). All the images were normalised using the internal control and the comparison of whole profiles was performed using the Dice similarity coefficient $\left(D_{s c}\right)$. The dendrogram was generated using the method of unweighted pair group with mathematical averages (UPGMA) at $1 \%$ position tolerance. The 10 different points were represented as numbering of $1 \mathrm{~B}$ until 10B on DGGE gels.

\section{Sequencing of DGGE Band}

The intense DGGE bands were excised, eluted with $50 \mu \mathrm{l}$ of TE buffer and incubated overnight at $4^{\circ} \mathrm{C}$. Eluted DNA from excised gel was used as DNA template for re-amplification using $16 \mathrm{~S}$ rDNA primers, 341f (with no GC-clamp) (5'-cct-acg-ggaggc-agc-ag-3') and 907R reverse(r) (Muyzer et al., 1997). The PCR products were purified using 


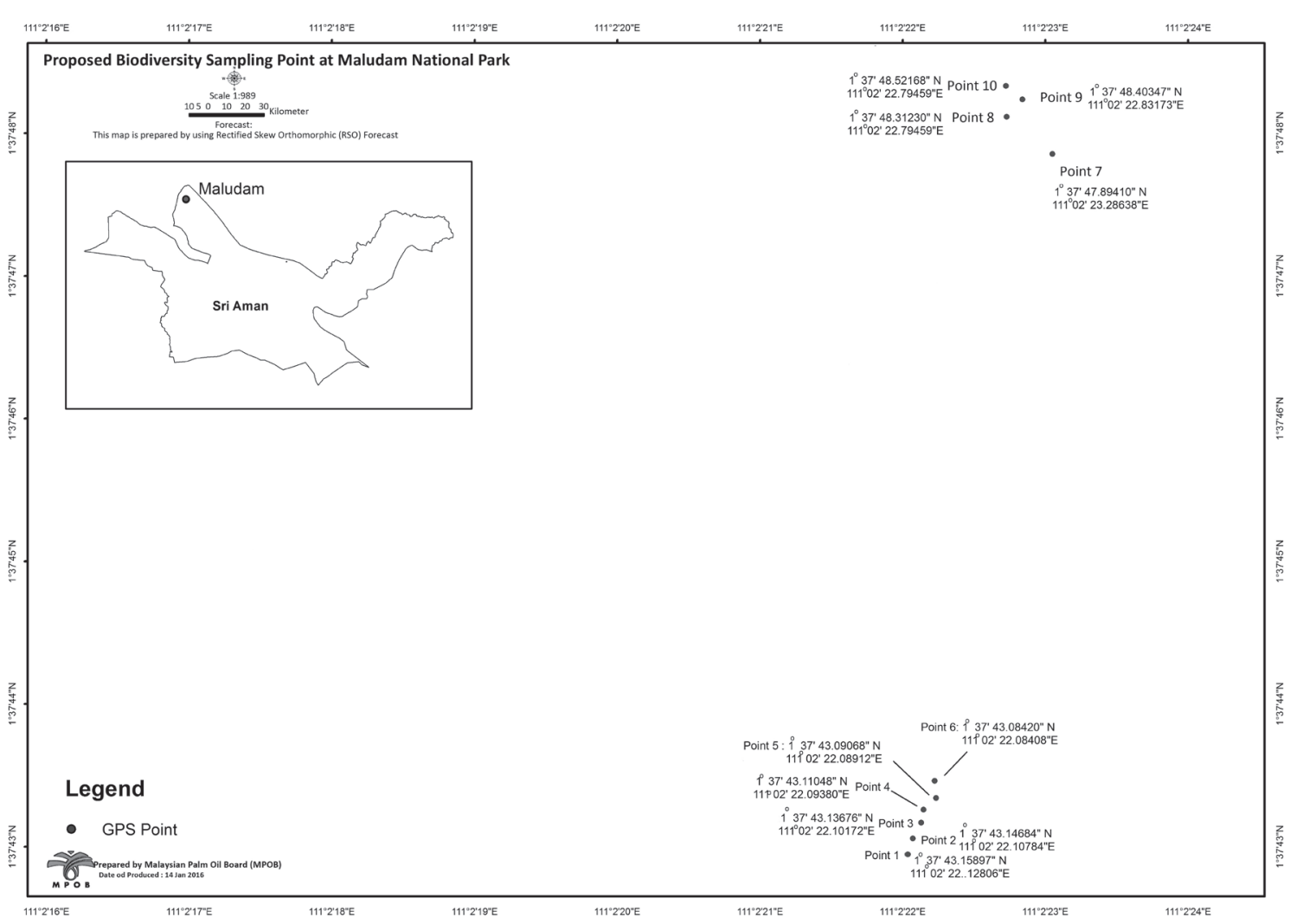

(a)

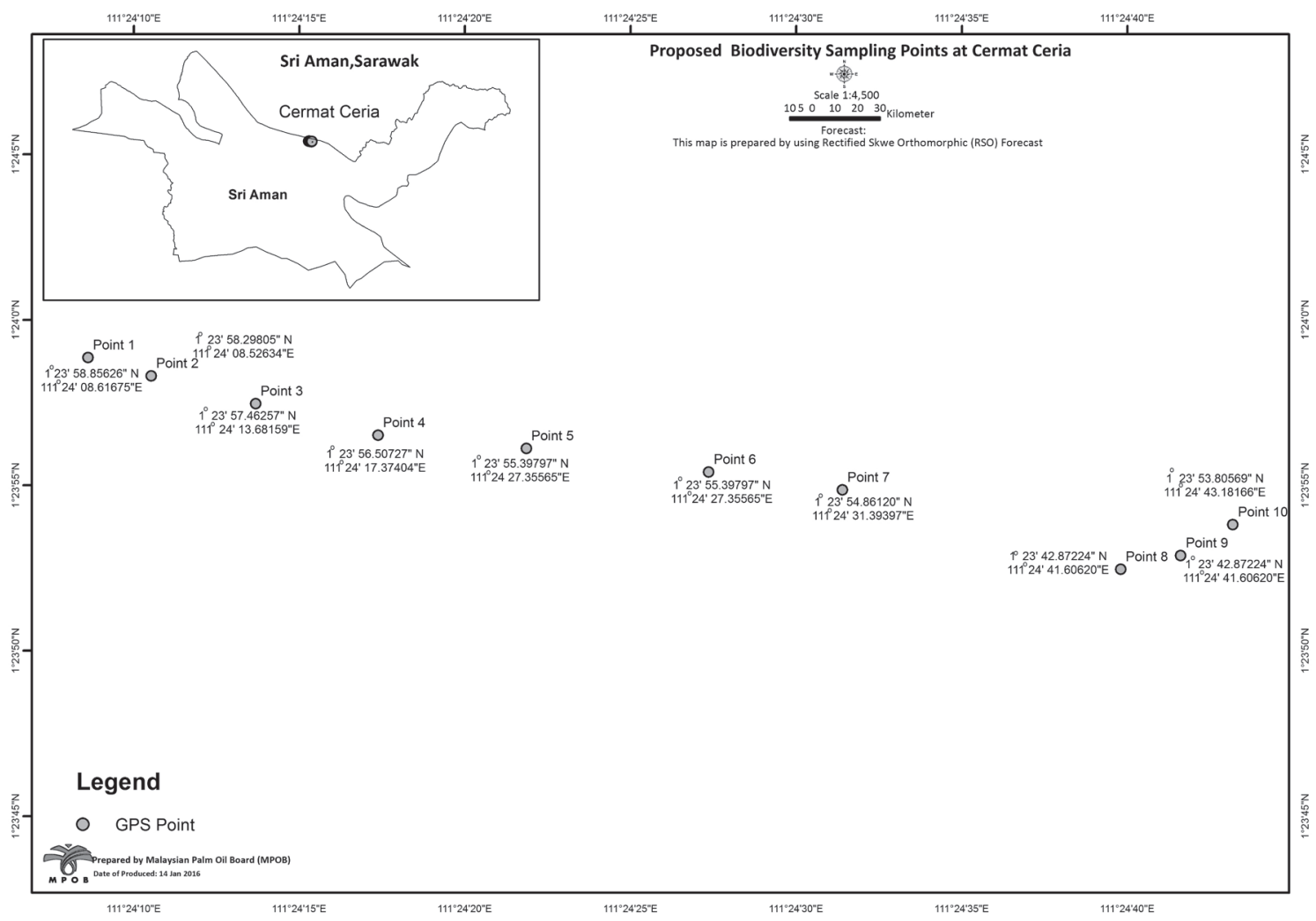

(b)

Figure 1. Biogeographical points located at Sri Aman, Sarawak, Malaysia. Maludam primary forest (a). Cermat Ceria logged-over forest (b). 
QIAquick gel extraction kits (QIAGEN, Inc., Valencia, CA) according to the manufacturer's instruction.

The PCR products were sent to First Base Laboratories (Malaysia) for sequencing. Sequence similarity searches were conducted using the nucleotide-nucleotide basic logic alignment search tool (BLASTn) of the NCBI GenBank database to identify the nearest relatives of the partially sequenced $16 S$ rRNA genes of excised bands.

\section{Phylogenetic Analysis}

The nucleotide sequences determined in this study were aligned, and Neighbor-Joining Trees were constructed using MEGA version 4.0 (Molecular Evolutionary Genetics Analysis) (http://www. megasoftware.net). Neighbor-Joining phylogenetic trees were constructed based on the position of the $16 S$ rRNA gene by using the Kimura two-parameter substitution model evaluated by 1000 bootstrap resamplings of the data, and nodes with bootstrap values were indicated.

\section{Statistics for Biodiversity Index}

The Shannon-Weaver biodiversity index $\left(H^{\prime}\right)$, is calculated as follows:

$$
H^{\prime}=-\sum_{i=1} p_{i} \ln p_{i}
$$

where $H$ is the Shannon's diversity index, $S$ is the total number of species in the community (richness), $P i$ is the proportion of $S$ made up of the $i$ th species. Shannon's index accounts for both abundance and evenness of the species present. The proportion of species $i$ relative to the total number of species $\left(p_{i}\right)$ is calculated, and then multiplied by the natural logarithm of this proportion $\left(\ln p_{i}\right)$. The resulting product is summed across species, and multiplied by -1 (Hill, 1973).

\section{Berger-Parker Dominance Index}

The Berger-Parker dominance index expresses the proportional importance of the most abundant species (the dominant species). It is a simple measure of the numerical importance of the most abundant species. $\mathrm{d}=\mathrm{N}_{\max } / \mathrm{N}$ where, $N_{\max }$ is the number of individuals in the most abundant species, and $N$ is the total number of individuals in the sample (Hill, 1973).

\section{RESULTS AND DISCUSSION}

Phoretix 1D software has been utilised to analyse the DGGE fingerprints by using dice coefficient and UPGMA in Figure 2. The dendrogram was constructed with the $16 \mathrm{~S}$ rDNA bacterial communities fingerprint of Maludam and Cermat Ceria. The differences between DGGE band profiles were indicated by the percentage of similarity. The major cluster (cluster I and II) shows $40 \%$ genetic similarity while the minor cluster (cluster III) showed the indistinguish profile with lower genetic similarity at 20\% in Maludam, lane 6B.

Shannon-Weaver prokaryotic biodiversity index in Table 2 showed that Cermat Ceria was less diverse at 7.63 compared to Maludam, 7.75. The results for Berger-Parker concurred, where the most diversified population was Maludam compared to Cermat Ceria. Total bacteria identified in Maludam was also higher compared to Cermat Ceria with 17501 and 11236 similarities respectively (Table 3). The similarity species indicates sequences producing significant alignments (Madden, 2002). This suggests higher diversity of bacterial population in the primary forest compared to logged-over forest as shown in Table 3. The uncultured soil bacterium in Table 3 was the dominant bacteria in Maludam with 9232 similarities while, the uncultured bacterium was the dominant bacteria in Cermat Ceria with 5416 similarities.

The distribution of microbial phyla for both peat ecosystems is shown in Figure 3 and the pie charts were constructed by calculating the percentage of frequency as indicated in Figure 4. Unclassified bacteria was found to be the dominant bacterial phyla in both peat ecosystems (Figure 3). The unclassified bacteria dominated up to $69 \%$ and $65 \%$ of the total bacterial community in Maludam and Cermat Ceria, respectively (Figures $3 a$ and $3 b$ ). These findings suggested that unclassified bacteria could potentially be classified as a novel taxa candidate (Logan et al., 2009). Acidobacteria, Actinobacteria and $\alpha$-Proteobacteria recorded the same percentage, $8 \%$ from the total bacterial population in Maludam. However, the population of Acidobacteria was at $8 \%$ in Maludam compared to $19 \%$ in Cermat Ceria. Therefore, Acidobacteria was the second most prevalent phyla after unclassified bacteria in Cermat Ceria while, Firmicutes population was lower at $2 \%$ in Maludam compared to 5\% in Cermat Ceria. In addition, the population of Actinobacteria and $\alpha$-Proteobacteria also decreased from both $8 \%$ to $6 \%$ and 3\% in Maludam and Cermat Ceria, respectively. Nitrospirae was found in Cermat Ceria while Cyanobacteria was found in Maludam. However, the populations of Nitrospirae and Cyanobacteria cannot be related to the forest clearing since only one species can be identified in the respective area.

In the phyla of Acidobacteria (Table 3), Acidobacteria bacterium was the dominant prokaryotes in Maludam and Cermat Ceria with 606 and 1473 similarities occurrence, respectively. Even though Cermat Ceria harboured a higher number of similarities with 1668 compared to Maludam with 660 , the diversity of bacterial species was comparable 


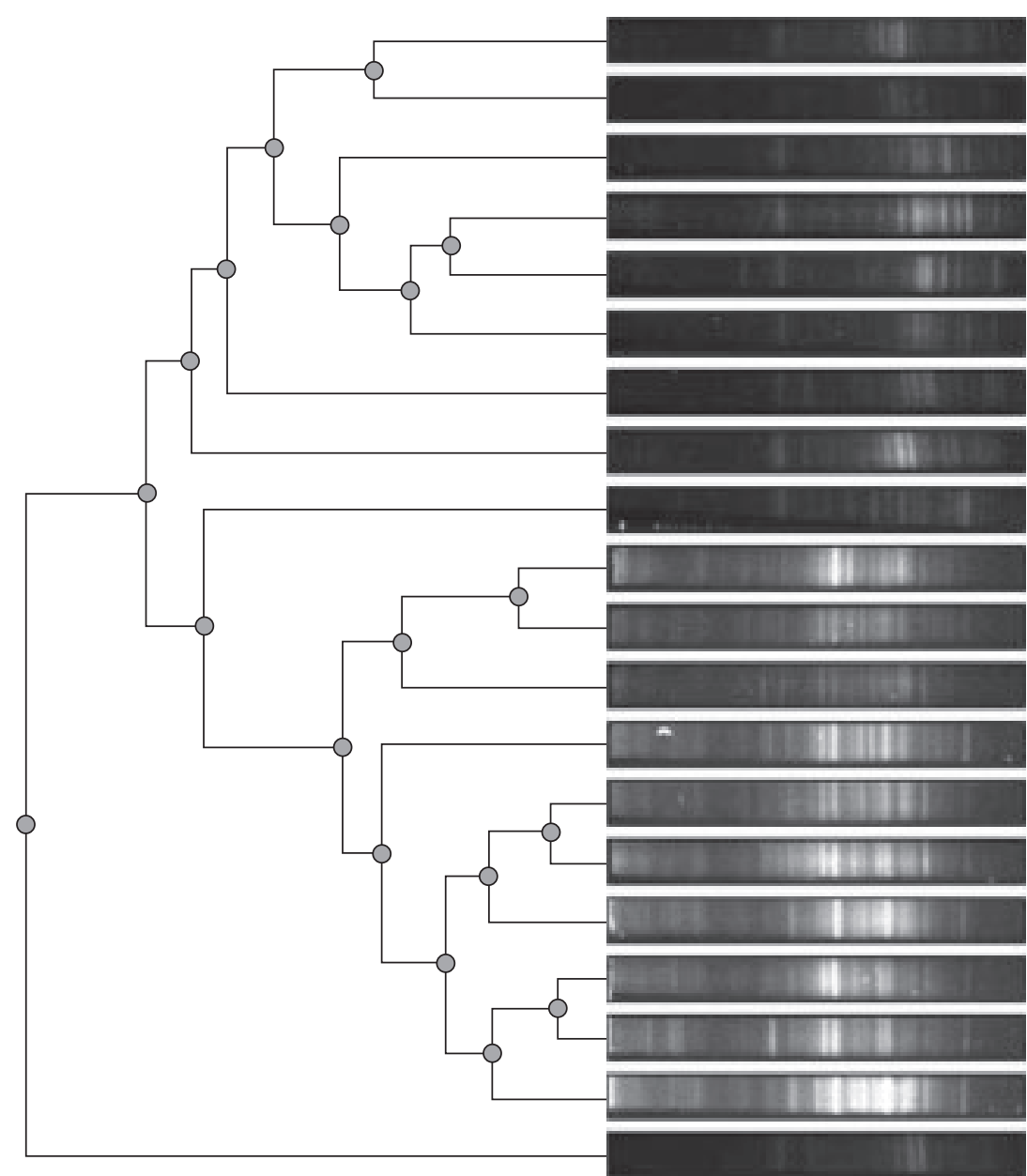

Maludam 10B

Maludam 9B

Maludam 5B

Maludam 4B

Maludam 3B

Maludam 2B

Maludam 7B

Maludam 8B

Maludam 1B

Cermat Ceria 10B

Cermat Ceria 8B

Cermat Ceria 9B

Cermat Ceria 7B

Cermat Ceria 6B

Cermat Ceria 5B

Cermat Ceria 1B

Cermat Ceria 4B

Cermat Ceria 3B

Cermat Ceria 2B

Maludam 6B

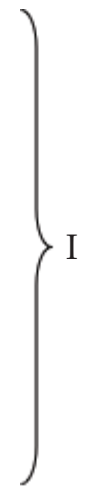


(a)

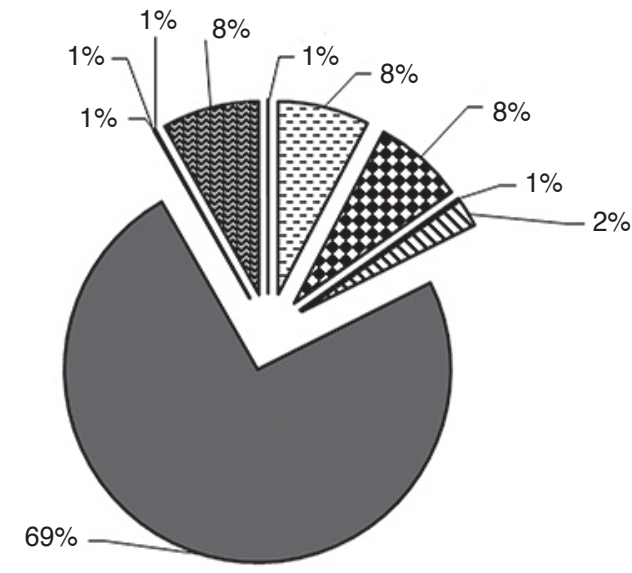

Acidobacteria

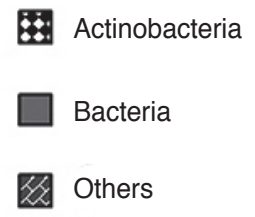

(b)
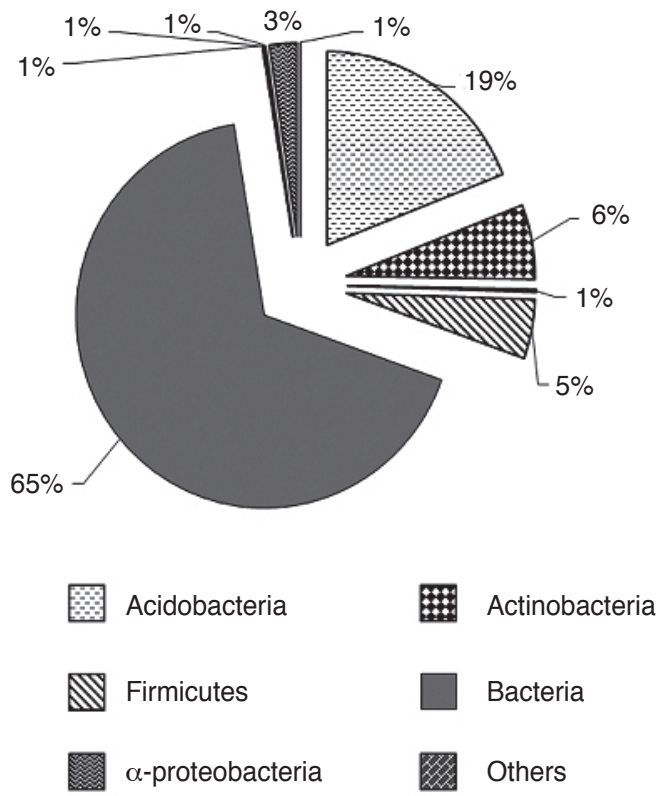

Figure 3. Prokaryotic phyla for deep peat forest and logged-over deep peat forest in Sarawak. Primary deep peat forest at Maludam (a). Logged-over deep peat forest at Cermat Ceria (b).

clean cleared area. In this study, the changes can be seen with the presence of Actinobacteria species as shown in Table 3. Clear differences in the number of uncommon bacterial species, which differed from 53 species in Maludam to six species in Cermat Ceria. The majority of known soil Actinobacteria is aerobic (Kutilek and Nielsen, 2015) but their richness in peat indicates at least a tolerance to anaerobic conditions, as viable aerobic Actinobacteria have been isolated from deep and anaerobic peat (Kotiaho et al., 2013). The genus Mycobacterium spp. (Table 3) dominated in both locations with Maludam harboring more diversified Mycobacterium species. A total of 27 Mycobacterium species were identified in Maludam compared to three in Cermat Ceria. However, Mycobacterium tuberculosis was the most dominant species with 141 similarities occurrence while, Actinobacterium spp. was the most dominant in Maludam with 225 similarities occurrence. Actinobacteria is a large phylum of physiologically heterogeneous bacteria found abundant in diverse environments (Stevenson and Hallsworth, 2014). It is an important decomposers of organic matter, especially cellulose, in Sphagnum peat (Moore et al., 2015). Mycobacterium avium and M. intracellulare present in Maludam were the common nontuberculous Mycobacteria detected in soil (Pribylova et al., 2011). The abundance of these Mycobacterium species in Maludam is because of the richer animal diversity in the forest. The forest soil is easily contaminated by fertilisation with manure or liquid dung or by water contaminated by animal faeces.
The changes in microbial diversity can be clearly observed in the phyla of Actinobacteria (Table 3) and $\alpha$-Proteobacteria (Table 3). These two phyla had highest differences in bacterial species. The logging activity has clearly resulted in the reduction of the Actinobacteria and $\alpha$-Proteobacteria species diversity in the peat forest from 506 to 218 and 475 to 101 species, respectively. The uncommon bacterial species in the phylum of $\alpha$-Proteobacteria reduced significantly from 57 to nine species. Interestingly, this trend was different for Actinobacterium (Table 3). The genus Mycobacterium was largely affected by the logging activity as shown in Table 3 . The Mycobacterium species was reduced from 29 species to only three species in Cermat Ceria.

The phyla $\alpha$-Proteobacteria was dominated by Alpha proteobacterium in both Maludam and Cermat Ceria with 164 and 31 similarities occurrence, respectively. The $\alpha$-Proteobacteria population was more diverse in Maludam compared to Cermat Ceria with 66 different species (Figure 4) in Maludam compared to 18 species in Cermat Ceria (Figure 4). Analysis of the stability of phyla before and after the logging activity showed that the Proteobacteria, mainly dominated by $\alpha$-Proteobacteria was not conserved after the forest clearing. The number of Hyphomicrobiaceae bacterium which is the dominant bacterial species of $\alpha$-Proteobacteria was higher in Maludam, 27.72\% compared to Cermat Ceria, 7.51\% (Table 3). This trend was also similar with Rhizobiales bacterium which was also higher in Maludam, $14.85 \%$ compared to Cermat Ceria, $5.26 \%$ (Table 3). 
TABLE 3. UNCLASSIFIED BACTERIUM, ACIDOBACTERIUM, ACTINOBACTERIUM, $\alpha$-PROTEOBACTERIUM AND FIRMICUTES SPECIES ISOLATED FROM PRIMARY DEEP PEAT, MALUDAM AND LOGGED-OVER FOREST, CERMAT CERIA AT SRI AMAN, SARAWAK, MALAYSIA

\begin{tabular}{|c|c|c|c|}
\hline \multirow[t]{2}{*}{ Phyla } & \multirow[t]{2}{*}{ Common/ Uncommon } & \multicolumn{2}{|c|}{ Sites } \\
\hline & & Maludam & Cermat Ceria \\
\hline \multirow{15}{*}{$\begin{array}{l}\text { Unclassified } \\
\text { Bacterium }\end{array}$} & (a) Common & Bacterium enrichment culture (13) & Bacterium enrichment culture (9) \\
\hline & & Forest soil bacterium (101) & Forest soil bacterium (42) \\
\hline & & Uncultured bacteria (5) & Uncultured bacteria (1) \\
\hline & & Uncultured bacterium (6 311) & Uncultured bacterium (5 416) \\
\hline & Total similarity species & 6430 & 5468 \\
\hline & (b) Uncommon & Bacterium SCS_30Z1_39 (1) & Bacterium ADV403 (1) \\
\hline & & Prokaryote clone (13) & Bacterium ADV70 (1) \\
\hline & & Uncultured endolithic bacterium (1) & Iron-reducing bacterium (1) \\
\hline & & Uncultured eubacterium (1) & Soil bacterium (222) \\
\hline & & Uncultured soil bacterium (9232) & Uncharacterised organism (14) \\
\hline & & & Uncultured prokaryote (3) \\
\hline & & & Uncultured proteobacterium (124) \\
\hline & Total similarity species & 9248 & 3363 \\
\hline & Overall & & \\
\hline & & 15678 similarities & 8831 similarities \\
\hline \multirow[t]{15}{*}{ Acidobacteria } & (a) Common & Acidobacteria bacterium (606) & Acidobacteria bacterium (1473) \\
\hline & & Acidobacteriaceae bacterium (1) & Acidobacteriaceae bacterium (74) \\
\hline & & Acidobacteriales bacterium (11) & Acidobacteriales bacterium (24) \\
\hline & & Acidobacterium (2) & Acidobacterium (41) \\
\hline & & Bacterium Ellin (7) & Bacterium Ellin (13) \\
\hline & & Candidatus koribacter sp. (20) & Candidatus koribacter sp. (24) \\
\hline & & Holophaga sp. (6) & Holophaga sp. (3) \\
\hline & Total similarity species & 653 & 1652 \\
\hline & (b) Uncommon & Acidipila rosea (1) & Edaphobacter sp. (1) \\
\hline & & Acidipila sp. (1) & Rhodanobacter sp. (5) \\
\hline & & Acidobacterium capsulatum (2) & Sphingobacteriales bacterium (1) \\
\hline & & Geothrix sp. (1) & Telmatobacter sp. (9) \\
\hline & & Solibacter sp. (2) & \\
\hline & Total similarity species & 7 & 16 \\
\hline & Overall & 660 similarities & 1668 similarities \\
\hline \multirow[t]{17}{*}{ Actinobacteria } & (a) Common & Actinoallomurus sp. (7) & Actinoallomurus sp. (2) \\
\hline & & Actinobacterium (225) & Actinobacterium (32) \\
\hline & & Actinomyces sp. (3) & Actinomyces sp. (4) \\
\hline & & Actinomycetales bacterium (3) & Actinomycetales bacterium (1) \\
\hline & & Sporichthyaceae bacterium (2) & Sporichthyaceae bacterium (2) \\
\hline & & Thermomonosporaceae bacterium (3) & Thermomonosporaceae bacterium (1) \\
\hline & Total similarity species & 324 & 42 \\
\hline & (b) Uncommon & Acidimicrobidae bacterium (1) & Geothrix sp. (2) \\
\hline & & Acidimicrobium sp. (1) & Mycobacterium bovis (15) \\
\hline & & Actinomycetales bacterium (3) & Mycobacterium canettii (13) \\
\hline & & Actinomycete species (1) & Mycobacterium tuberculosis (141) \\
\hline & & Dactylosporangium sp. (1) & Rhodococcus erythropolis (1) \\
\hline & & Kitasatospora niigatensis (1) & Unknown Actinomycete (4) \\
\hline & & Mycobacterium celatum (6) & \\
\hline & & Mycobacterium haemophilum (3) & \\
\hline & & Marmoricola sp. (3) & \\
\hline & & Mycobacteriaceae bacterium (1) & \\
\hline
\end{tabular}


TABLE 3. UNCLASSIFIED BACTERIUM, ACIDOBACTERIUM, ACTINOBACTERIUM, $\alpha$-PROTEOBACTERIUM AND FIRMICUTES SPECIES ISOLATED FROM PRIMARY DEEP PEAT, MALUDAM AND LOGGED-OVER FOREST, CERMAT CERIA AT SRI AMAN, SARAWAK, MALAYSIA (continued)

\begin{tabular}{|c|c|c|c|}
\hline \multirow[t]{2}{*}{ Phyla } & \multirow[t]{2}{*}{ Common/ Uncommon } & \multicolumn{2}{|c|}{ Sites } \\
\hline & & Maludam & Cermat Ceria \\
\hline & & Mycobacterium aemonae (1) & \\
\hline & & Mycobacterium alsiensis (1) & \\
\hline & & Mycobacterium angelicum (2) & \\
\hline & & Mycobacterium asiaticum (2) & \\
\hline & & Mycobacterium avium (17) & \\
\hline & & Mycobacterium bourgelatii (3) & \\
\hline & & Mycobacterium branderi (2) & \\
\hline & & Mycobacterium celatum (6) & \\
\hline & & Mycobacterium colombiense (1) & \\
\hline & & Mycobacterium fragae (1) & \\
\hline & & Mycobacterium haemophilum (3) & \\
\hline & & Mycobacterium intracellulare (31) & \\
\hline & & Mycobacterium kansasii (1) & \\
\hline & & Mycobacterium kyorinense (6) & \\
\hline & & Mycobacterium malmoense (3) & \\
\hline & & Mycobacterium marinum (7) & \\
\hline & & Mycobacterium noviomagense (1) & \\
\hline & & Mycobacterium pseudoshottsii (1) & \\
\hline & & Mycobacterium riyadhense (2) & \\
\hline & & Mycobacterium shimoidei (1) & \\
\hline & & Mycobacterium sp. (20) & \\
\hline & & Mycobacterium szulgai (3) & \\
\hline & & Mycobacterium timonense (2) & \\
\hline & & Mycobacterium ulcerans (3) & \\
\hline & & Mycobacterium yongonense (2) & \\
\hline & & Nocardioidaceae bacterium (1) & \\
\hline & & Nocardioides jensenii (3) & \\
\hline & & Nocardiopsis alba (1) & \\
\hline & & Nocardiopsis quinghaiensis (1) & \\
\hline & & Nonomuraea sp. (1) & \\
\hline & & Streptomyces albovinaceus (3) & \\
\hline & & Streptomyces californicus (1) & \\
\hline & & Streptomyces corchorusii (1) & \\
\hline & & Streptomyces enissocaesilis (1) & \\
\hline & & Streptomyces globisporus (1) & \\
\hline & & Streptomyces goraiensis (1) & \\
\hline & & Streptomyces lusitanus (1) & \\
\hline & & Streptomyces mutabilis (1) & \\
\hline & & Streptomyces parvulus (1) & \\
\hline & & Streptomyces sp. (16) & \\
\hline & & Streptomyces sulphureus (1) & \\
\hline & & Streptomyces thermocarboxydus (1) & \\
\hline & & Uncultured Actinomycete (4) & \\
\hline & Total similarity speciesl & 182 & 176 \\
\hline & Overall & 506 similarities & 218 similarites \\
\hline \multirow[t]{10}{*}{$\alpha$-Proteobacteria } & (a) Common & Alpha proteobacterium (164) & Alpha proteobacterium (31) \\
\hline & & Bradyrhizobiaceae bacterium (8) & Bradyrhizobiaceae bacterium (4) \\
\hline & & Bradyrhizobium sp. (57) & Bradyrhizobium sp. (1) \\
\hline & & Hyphomicrobiaceae bacterium (38) & Hyphomicrobiaceae bacterium (28) \\
\hline & & Methylocystaceae bacterium (2) & Methylocystaceae bacterium (1) \\
\hline & & Paracoccus sp.(1) & Paracoccus sp. (1) \\
\hline & & Pseudolabrys sp. (5) & Pseudolabrys sp. (9) \\
\hline & & Rhizobiales bacterium (25) & Rhizobiales bacterium (15) \\
\hline & & Xanthobacteraceae bacterium (2) & Xanthobacteraceae bacterium (2) \\
\hline & Total similarity species & 302 & 92 \\
\hline
\end{tabular}


TABLE 3. UNCLASSIFIED BACTERIUM, ACIDOBACTERIUM, ACTINOBACTERIUM, $\alpha$-PROTEOBACTERIUM AND FIRMICUTES SPECIES ISOLATED FROM PRIMARY DEEP PEAT, MALUDAM AND LOGGED-OVER FOREST, CERMAT CERIA AT SRI AMAN, SARAWAK, MALAYSIA (continued)

\begin{tabular}{|c|c|c|c|c|}
\hline \multirow[t]{2}{*}{ Phyla } & \multirow{2}{*}{\multicolumn{2}{|c|}{ Common/ Uncommon }} & \multicolumn{2}{|c|}{ Sites } \\
\hline & & & Maludam & Cermat Ceria \\
\hline & & Uncommon & Acetobacteraceae bacterium (4) & Alphaproteobacteria bacterium (1) \\
\hline & & & Acidocella aluminiidurans (2) & Altererythrobacter sp. (1) \\
\hline & & & Acidocella facilis (1) & Beijerinckia sp. (1) \\
\hline & & & Acidocella sp. (32) & Erythrobacter sp (1) \\
\hline & & & Afipia sp. (1) & Magnetococcus sp. (1 \\
\hline & & & Agrobacterium albertimagni (1) & Mesorhizobium sp. (1) \\
\hline & & & Albidovulum xiamenense (1) & Methylocapsa acidiphila (1) \\
\hline & & & Bartonella elizabethae (1) & Methylocapsa sp. (1) \\
\hline & & & Bartonella sp. (2) & Rhodoblastus acidophilus (1) \\
\hline & & & Blastochloris sp. (1) & \\
\hline & & & Bradyrhizobium elkanii (18) & \\
\hline & & & Bradyrhizobium genosp (1) & \\
\hline & & & Bradyrhizobium japonicum (1) & \\
\hline & & & Brevundimonas diminuta (1) & \\
\hline & & & Brevundimonas sp. (1) & \\
\hline & & & Brucella sp. (1) & \\
\hline & & & Chelativorans multitrophicus (3) & \\
\hline & & & Chelativorans sp. (1) & \\
\hline & & & Dongia sp. (1) & \\
\hline & & & Ensifer adhaerens (9) & \\
\hline & & & Ensifer sp. (14) & \\
\hline & & & Green Bay ferromanganous (2) & \\
\hline & & & Micronodule bacterium (2) & \\
\hline & & & Hyphomicrobium sp.(1) & \\
\hline & & & Labrenzia sp.(1) & \\
\hline & & & Mesorhizobium loti (1) & \\
\hline & & & Methylobacterium sp.(1) & \\
\hline & & & Methylocystis sp. (3) & \\
\hline & & & Methyloligella solikamskensis (1) & \\
\hline & & & Neorhizobium alkalisoli (1) & \\
\hline & & & Novosphingobium subterraneum (1) & \\
\hline & & & Ochrobactrum intermedium (1) & \\
\hline & & & Ochrobactrum sp. (2) & \\
\hline & & & Ochrobactrum tritici (1) & \\
\hline & & & Oligotropha sp. (1) & \\
\hline & & & Rhizobiaceae bacterium (9) & \\
\hline & & & Rhizobium herbae (1) & \\
\hline & & & Rhizobium sp.(5) & \\
\hline & & & Rhodobacteraceae bacterium (2) & \\
\hline & & & Rhodobacterales bacterium (1) & \\
\hline & & & Rhodoplanes roseus (1) & \\
\hline & & & Rhodoplanes serenus (1) & \\
\hline & & & Rhodoplanes sp. (92) & \\
\hline & & & Rhodospirillaceae bacterium (4) & \\
\hline & & & Rhodospirillales bacterium (3) & \\
\hline & & & Rhodovulum sp.(1) & \\
\hline & & & Roseobacter sp. (1) & \\
\hline & & & Shinella kummerowiae (1) & \\
\hline & & & Shinella sp. (6) & \\
\hline & & & Sinorhizobium fredii (3) & \\
\hline & & & Sinorhizobium medicae (3) & \\
\hline & & & Sinorhizobium meliloti (5) & \\
\hline & & & Sinorhizobium sp. (13) & \\
\hline & & & Sphingomonadaceae bacterium (1) & \\
\hline & & & Thermophilic bacterium (1) & \\
\hline
\end{tabular}


TABLE 3. UNCLASSIFIED BACTERIUM, ACIDOBACTERIUM, ACTINOBACTERIUM, $\alpha$-PROTEOBACTERIUM AND FIRMICUTES SPECIES ISOLATED FROM PRIMARY DEEP PEAT, MALUDAM AND LOGGED-OVER FOREST, CERMAT CERIA AT SRI AMAN, SARAWAK, MALAYSIA (continued)

\begin{tabular}{|c|c|c|c|}
\hline \multirow[t]{2}{*}{ Phyla } & \multirow[t]{2}{*}{ Common/ Uncommon } & \multicolumn{2}{|c|}{ Sites } \\
\hline & & Maludam & Cermat Ceria \\
\hline & & $\begin{array}{l}\text { Thermovum composti (2) } \\
\text { Uncultured Stella sp. (1) }\end{array}$ & \\
\hline & Total similarity species & 173 & 9 \\
\hline & Overall & 475 similarities & 101 similarities \\
\hline \multirow[t]{22}{*}{ Firmicutes } & (a) Common & Bacillus amyloliquefaciens (1) & Bacillus amyloliquefaciens (23) \\
\hline & & Bacillus sp. (3) & Bacillus sp. (21) \\
\hline & & Bacillus subtilis (2) & Bacillus subtilis (36) \\
\hline & & Enterococcus sp.(2) & Enterococcus sp. (1) \\
\hline & & Firmicutes bacterium (160) & Firmicutes bacterium (316) \\
\hline & & Paenibacillus sp. (2) & Paenibacillus sp. (1) \\
\hline & Total similarity species & 170 & 398 \\
\hline & (b) Uncommon & Acidithiobacillus sp. (1) & Bacillus atrophaeus (1) \\
\hline & & Anoxybacillus sp. (1) & Bacillus licheniformis (1) \\
\hline & & Bacillaceae bacterium (1) & Bacillus methylotrophicus (2) \\
\hline & & Carnobacterium viridans (1) & Bacillus polyfermenticus (1) \\
\hline & & Clostridia bacterium (2) & Bacillus stearothermophilus (1) \\
\hline & & Desulfotomaculum acetoxidans (1) & Bacillus tequilensis (7) \\
\hline & & Exiguobacterium sp. (2) & Bacillus thuringiensis (1) \\
\hline & & Lysinibacillus fusiformis (2) & Endophytic bacterium (1) \\
\hline & & Thermoanaerobacteraceae bacterium (1) & Lactobacillus plantarum (1) \\
\hline & & & Paenibacillus borealis (1) \\
\hline & & & Streptococcus agalactiae (1) \\
\hline & & & Streptococcus sanguinis (1) \\
\hline & & & Virgibacillus sp. (1) \\
\hline & Total similarity species & 12 & 20 \\
\hline & Overall & 182 similarities & 418 similarities \\
\hline
\end{tabular}

Note: Number indicates total similarity species.

Rhizobiales bacterium which is in the families of Methylocystaceae and Hyphomicrobiaceae together with Bradyrhizobiaceae represent as key bacteria involved in soil $\mathrm{C}$ and $\mathrm{N}$ cycling (Acosta-Martinez et al., 2010). This metabolically diverse group of organisms can be recognised in several subphyla of four, which are $\alpha-, \beta-, \gamma-$ and $\delta$-Proteobacteria. The predominance of many bacteria under pasture, including Acidobacteriaceae, may reflect the combined effects of every different root systems and their exudates (i.e., type and amounts), and differences in soil properties (i.e., lower soil $\mathrm{pH}$, less disturbance).

The dominant species in the phylum Firmicutes is shown in Table 3. Unidentified Firmicutes bacterium was the dominant species found in both ecosystems with 160 similarities occurrence in Maludam and 316 similarities occurrence in Cermat Ceria. Bacillus amyloliquefaciens was the dominant bacteria species identified in Cermat Ceria with 23 similarities occurrence. This bacteria was known as growth promoting bacteria, plant protector and involves in induction of Systemic Resistance (ISR) (Chowdhury et al., 2013). In fact, the Bacillus genus was more diverse in Cermat Ceria compared to Maludam with nine different species compared to Maludam with three different species (Table 3). Firmicutes such as Bacillus and Paenibacillus were well-characterised plant-associated genera with antagonistic properties towards fungal plant pathogens (Koberl et al., 2011).

Both sites had a total number of 32 common bacterial species of the prevalent phylum. Each phylum - $\alpha$-Proteobacteria, Acidobacteria, Actinobacteria, Firmicutes and unclassified Bacteria comprised of nine, seven, six, six and four common species, respectively (Table 3). Conversely, the distinctive species of $\alpha$-Proteobacteria, Actinobacteria and Acidobacteria at Maludam and Cermat Ceria reduced from 57 to 9,53 to 6 and 5 to 4 , respectively (Table3). However, the distinctive species of Firmicutes and unclassified Bacteria increased 


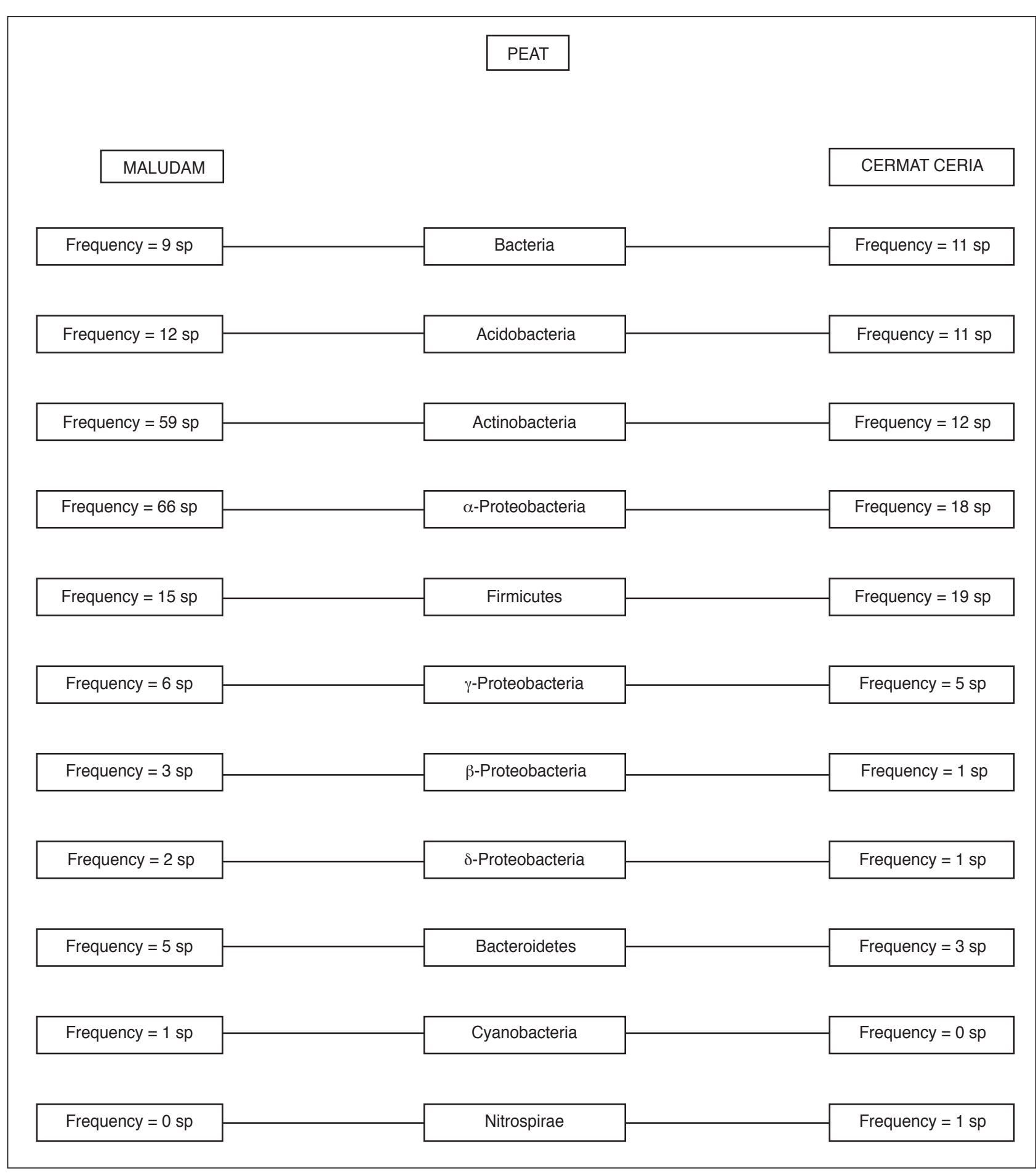

Note: $\mathrm{sp}$ - species.

Figure 4. Species frequency within prokaryotic phyla in primary deep peat Maludam and Cermat Ceria at Sri Aman, Sarawak, Malaysia.

from 9 to 13 and 5 to 7 , respectively (Table 3). The distinct species were found in Maludam such as Acidobacterium capsulatum, Solibacter, Mycobacterium intracellulare, Rhodoplanes sp., Clostridia bacterium, Exiguobacterium sp. and Lysinibacillus fusiformis. Whereas, the distinct species were found in Cermat Ceria such as Telmatobacter, Mycobacterium tuberculosis and Bacillus tequilensis. These data showed that many species of $\alpha$-Proteobacteria and
Actinobacteria disappeared after forest clearing. For example, the genus Rhodoplanes can be isolated from pond water (Okamura et al., 2009) and soil (Lakshmi et al., 2009) were consisted of a group of purple nonsulphur, denitrifying bacteria. The members of this genus can be found widely in the soil which shows that they are potentially involved in nitrogen cycling and energy transformation in soils (Okamura et al., 2009). 
Species frequency within prokaryotic phyla in Figure 4 showed the presence of bacteria that occurred more than one time as one single species. Figure 4 was constructed based on the phylogenetic tree (data not shown) constructed for the analysis processes. Results showed the reduction of bacterial species in $\alpha$-Proteobacteria, Actinobacteria and Acidobacteria from 66, 59 and 16 species to 18,12 and 11 bacterial species for Maludam and Cermat Ceria, respectively. Conversely, the diversity of Firmicutes increased from 15 different bacterial species to 19 species. This data also proved that the logging activity affects the population diversity of the microbial species in the primary forest.

The effect of peat area degradation on the development of the peat area for agricultural purposes should be completely monitored. The physical environmental changes might also affect the microbial population before and after forest clearing. Firdaus et al. (2011) stated that the percentage of fibre content, volumetric water content and saturated hydraulic conductivity were not significantly affected by the logging process. However, the gravimetric water content, loss on ignition and total porosity were significantly higher in the drained secondary peat swamp forest, while ash content, bulk density, surface soil temperature and bearing capacity were significantly higher in the cleared site of drained secondary peat swamp forest. Therefore, the understanding of the bacterial diversity of soil in the affected area is essential since the bacterial diversity and soil function are correlated. The microbes can be phosphate solubilising, nitrogen fixing and plant disease suppressing which help to improve the crop yield and protection. Hence, PCR-DDGE technique was performed in order to conduct such studies (LucenaPadrós et al., 2015). This is due to the immediate result that can be provided in a qualitative and semi-quantitative way. However, a single species of DGGE band might also have multiple copies of $16 \mathrm{~S}$ $r R N A$ gene. Therefore, the application of cloning vector can be applied as reported by Sekiguchi et al. (2001). The cloning vector is highly specific to one single strain which enables the differentiation of the $16 S$ rRNA gene copies because one gene can only be ligated with one cloning vector (Sekiguchi et al., 2001). Hence, the multicopies of $16 S r R N A$ gene can be differentiated to distinguish different individual of the same species. Therefore, the application of DGGE coupled with cloning vector can be utilised to overcome this issue.

\section{CONCLUSION}

Microbial biodiversity in Maludam showed significant differences in the number of bacterial species compared to Cermat Ceria. The bacterial population was also more diverse in Maludam compared to Cermat Ceria. The application of DGGE provides an early indicator that the logging activity can alter the bacterial population in the peat soil. However, the overall picture of the taxonomic composition can be made broader and more accurate through the application of next generation sequencing (NGS) since it avoids the biasness during PCR amplification and DGGE gel excision.

\section{ACKNOWLEDGEMENT}

We would like to thank the Director-General and the Director of Biological Research Division, MPOB for the permission to publish this article. This research is supported by the MPOB Research Fund: R009711000.

\section{REFERENCES}

ACOSTA-MARTINEZ, V; DOWD, S E; BELL, C; LASCANO, R; BOOKER, J D; ZOBECK, T M and UPCHURCH, D R (2010). Microbial community comparison as affected by dryland cropping systems and tillage in a semiarid sandy soil. Diversity, 2: 910-931.

BALDRIAN, P; KOLARÍK, M; STURSOVÁ, M; KOPECKÝ, J; VALÁŠKOVÁ, V; V`ETROVSKÝ, T; ZIF CÁKOVÁ, L; SNAJDR, J; RÍDL, J; VLCEK, Cand VO`RÍŠKOVÁ, J (2012). Active and total microbial communities in forest soil are largely different and highly stratified during decomposition. ISME J., 6: 248-258.

CHOWDHURY, S P; DIETEL, K; RÄNDLER, M; SCHMID, M; JUNGE, H; BORRISS, R; HARTMANN, A and GROSCH, R (2013). Effects of Bacillus amyloliquefaciens FZB42 on lettuce growth and health under pathogen pressure and its impact on the rhizosphere bacterial community. PLoS One, 8: e68818.

COLE, L; BHAGWAT, S and WILLIS, K (2015). Long-term disturbance dynamics and resilience of tropical peat swamp forests. J. Ecology, 103: 16-30.

FIRDAUS, M S; GANDASECA, $S$ and AHMED, O $H$ (2011). Effect of drainage and land clearing on selected peat soil physical properties of secondary peat swamp forest. International J. Physical Sciences, 6: 5462-5466.

FOESEL, B U; NÄGELE, V; NAETHER, A; WÜST, P K; WEINERT, J; BONKOWSKI, M; LOHAUS, G; POLLE, A; ALT, F; OELMANN, Y; FISCHER, M; FRIEDRICH, M W and OVERMANN, J (2013). Determinants of Acidobacteria activity inferred from 
the relative abundances of $16 \mathrm{~S}$ rRNA transcripts in German grassland and forest soils. Environmental Microbiology, 16: 658-675.

FREEMAN, C; FENNER, $\mathrm{N}$ and SHIRSAT, A H (2012). Peatland geoengineering: an alternative approach to terrestrial carbon sequestration. Philosophical Transaction of the Royal Society A, 370: 4404-4421.

GOMEZ-BALDERAS, C D C; COCHET, N; BERT, V; TARNAUD, E and SARDE, C O (2014). 16S rDNA analysis of bacterial communities associated with the hyper accumulator Arabidopsis halleri grown on a Zn and Cd polluted soil. European J. Soil Biology, 60: $16-23$.

HILL, M O (1973). Diversity and evenness: a unifying notation and its consequences. Ecology, 54: 427-431.

HU, L; CAO, L and ZHANG, R (2014). Bacterial and fungal taxon changes in soil microbial community composition induced by short term biochar amendment in red oxidized loam soil. World J. Microbiology and Biotechnology, 30: 1085-1092.

KANOKRATANA, P; UENGWETWANIT, $\quad \mathrm{T}$; RATTANACHOMSRI, U; BUNTERNGSOOK, B; NIMCHUA, T; TANGPHATSORNRUANG, $S$; PLENGVIDHYA, V; CHAMPREDA, $\mathrm{V}$ and EURWILAICHITR, L (2011). Insights into the Phyogeny and metabolic potential of a primary tropical peat swamp forest microbial community by metagenomic analysis. Microbial Ecology, 61: 518528.

KOBERL, M; MULLER, H; RAMADAN, E M and BERG, G (2011). Desert farming benefits from microbial potential in arid soils and promotes diversity and plant health. PLoS One, 6: e24452.

KOTIAHO, $\mathrm{M}$; FRITZE, $\mathrm{H}$; MERIL $\ddot{A}, \quad \mathrm{P}$; TUOMIVIRTA, T; VÄLIRANTA, M; KORHOLA A; KAROFELD, E and TUITTILA, E S (2013). Actinobacteria community structure in the peat profile of boreal bogs follows a variation in the microtopographical gradient similar to vegetation. Plant Soil, 369: 103-114.

KUTÍLEK, M and NIELSEN, D R (2015). The smallest zoo and botanical microgardens. Soil. Springer, Netherlands. p. 21-30.

LAKSHMI, K V N S; SASIKALA, C and RAMANA, C V (2009). Rhodoplanes pokkaliisoli sp. nov., a phototrophic alphaproteobacterium isolated from a waterlogged brackish paddy soil. International J. Systematic and Evolutionary Microbiology, 59: 21532157.
LAUBER, C L; RAMIREZ, K S; AANDERUD, Z; LENNON, J and FIERER, N (2013). Temporal variability in soil microbial communities across land-use types. ISME J., 7: 1641-1650.

LLADÓ, S; ŽIFČÁKOVÁ, L; VĚTROVSKÝ, T; EICHLEROVÁ, I and BALDRIAN, P (2015). Functional screening of abundant bacteria from acidic forest soil indicates the metabolic potential of Acidobacteria subdivision 1 for polysaccharide decomposition. Biology and Fertility of Soils: 1-10.

LOGAN, N A; BERGE, O; BISHOP, A H; BUSSE, $\mathrm{H}$ J; DE VOS, P; FRITZE, D; HEYNDRICKX, M; KÄMPFER, P; RABINOVITCH, L; SALKINOJASALONEN, M S and SELDIN, L (2009). Proposed minimal standards for describing new taxa of aerobic, endospore-forming bacteria. International J. Systematic and Evolutionary Microbiology, 59: 21142121.

LUCENA-PADROS, H; JIMENEZ, E; MALDONADO-BARRAG AN, A; RODRÍGUEZ, J M and RUIZBARBA, J L (2015). PCR-DGGE assessment of the bacterial diversity in Spanish style green table-olive fermentations. International J. Food Microbiology, 205: 47-53.

MADDEN, T (2002). Chapter 6 - The BLAST sequence analysis tool. The NCBI Handbook (McEntyre, J and Ostell, J eds.). National Library of Medicine, Bethesda, MD. p. 1-18.

MENEZES-OLIVEIRA, V B; SCOTT-FORDSMAND, J J; SOARES, A M V M and AMORIM, M J B (2014). Development of ecosystems to climate change and the interaction with pollution - unpredictable changes in community structures. Applied Soil Ecology, 75: 24-32.

MISHRA, S; LEE, W, A; HOOIJER, A; REUBEN, S; SUDIANA, I M; IDRIS, A and SWARUP, S (2013). Microbial and metabolic profiling reveal strong influence of water table and land-use patterns on classification of degraded tropical peatlands. Biogeosciences Discuss, 10: 14009-14042.

MOORE, E K; VILLANUEVA, L; HOPMANS, E C; RIJPSTRA, W I C; METS, A; DEDYSH, S N and DAMSTÉ, J S S (2015). Abundant trimethylornithine lipids and specific gene sequences are indicative of planctomycete importance at the oxic/anoxic interface in sphagnum-dominated northern wetlands. Applied and Environmental Microbiology, 81: 6333-6344.

MUYZER, G; BRINKHOFF, T; NÜBEL, U; SANTEGOEDS, C; SCHÄFER, $C$ and WAWER, C (1997). Denaturing gradient gel electrophoresis 
(DGGE) in microbial ecology. Molecular Microbial Ecology Manual. Kulwer Academic Publishers, Netherlands. p. 1-27.

NAETHER, A; FOESEL, B U; NAEGELE, V; WÜST, $\mathrm{P}$ K; WEINERT, J; BONKOWSKI, M; ALT, F; OELMANN, Y; POLLE, A; LOHAUS, G; GOCKEL, S; HEMP, A; KALKO, E K V; LINSENMAIR, K E; PFEIFFER, S; RENNER, S; SCHÖNING, I; WEISSER, W W; WELLS, K; FISCHER, M; OVERMANN, $\mathrm{J}$ and FRIEDRICH, M W (2012). Environmental factors affect Acidobacterial communities below the subgroup level in grassland and forest soils. Applied and Environmental Microbiology, 78: 7398-7406.

OKAMURA, K; KANBE, T and HIRAISHI, A (2009). Rhodoplanes serenus sp. nov., a purple non-sulfur bacterium isolated from pond water. International J. Systematic and Evolutionary Microbiology, 59: 531-535.

OMAR, F N; ISMAEL, N H dan ALI, S R A (2011). Fungi associated with deep peat soil Sarawak. UMT $11^{\text {th }}$ International Annual Symposium on Sustainability Science and Management, 37: 239-245.

OVERMANN, J and TUSCHAK, C (1997). Phylogeny and molecular fingerprinting of green sulfur bacteria. Archieves of Microbiology, 167: 302309.

PAGE, S E; RIELEY, J O and BANKS, C J (2011). Global and regional importance of the tropical peatland carbon pool. Global Change Biology, 17: 798818.

PITERINA, A V and PEMBROKE, J T (2013). Use of PCR-DGGE based molecular methods to analyse microbial community diversity and stability during the thermophilic stages of an ATAD wastewater sludge treatment process as an aid to performance monitoring. ISRN Biotechnology. p. 1-13.

POERSCHMANN, J; KOSCHORRECK, $\mathrm{M}$ and GÓRECKI, T (2012). Organic matter in sediments of an acidic mining lake as assessed by lipid analysis. Part I: fatty acids. Science of the Total Environment, 414: 614-623.

PRIBYLOVA, R; SLANA, I; KAEVSKA, M; LAMKA, J; BABAK, V; JANDAK, J and PAVLIK, I (2011). Soil and plant contamination with Mycobacterium avium subsp paratuberculosis after exposure to naturally contaminated mouflon feces. Current Microbiology, 62: 1405-1410.
SEKIGUCHI, H: TOMIOKA, N: NAKAHARA, T and UCHIYAMA, H (2001). A single band does not always represent single bacterial strains in denaturing gradient gel electrophoresis analysis. Biotechnology Letters, 23: 1205-1208.

STAMPS, B W; LOSEY, N A; LAWSON, P A; BRADLEY, S and STEVENSON, B S (2014). Genome sequence of Thermoanaerobaculum aquaticum MP01T, the first cultivated member of Acidobacteria subdivision 23, isolated from a hot spring. Genome Announcements, 2: e00570-14.

STEVENSON, A and HALLSWORTH, J E (2014). Water and temperature relations of soil actinobacteria. Environmental Microbiology Reports, 6: 744-755.

TALBOT, J M; BRUNS, T D; TAYLOR, J W; SMITH, D P; BRANCO, S; GLASSMAN, S I; ERLANDSON, S; VILGALYS, R; LIAO, H-L and SMITH, M E (2014). Endemism and functional convergence across the North American soil mycobiome. Proc. of the National Academy of Sciences, USA, 111: 6341-6346.

TRIVEDI, P; ANDERSON, I C and SINGH, B K (2013). Microbial modulators of soil carbon storage: integrating genomic and metabolic knowledge for global prediction. Trends Microbiology, 21: 641-651.

URBANOVÁ, M; ŠNAJDR, J and BALDRIAN, $P$ (2015). Composition of fungal and bacterial communities in forest litter and soil is largely determined by dominant trees. Soil Biology and Biochemistry, 84: 53-64.

VAESSEN, T; VERWER, C; DEMIES, M; KALIANG, $\mathrm{H}$ and VAN DER MEER, P J (2011). Comparison of termite assemblages along a land-use gradient on peat areas in Sarawak, Malaysia. J. Tropical Forest Science, 23: 196-203.

ZHANG, J; LAI, T; HE, Y; YAN, B; ZHANG, Y and FAN, H (2014). Effects of an underground in situ pipe eco-farming system on mangrove bacterial communities in the Beilunhe Estuary, Guangxi, China. Ecological Engineering, 68: 65-71.

ZHALNINA, K; DIAS, R; DE QUADROS, P D; DAVIS-RICHARDSON, A; CAMARGO, F A; CLARK, I M; MCGRATH, S P; HIRSCH, P R and TRIPLETT, E W (2015). Soil pH determines microbial diversity and composition in the park grass experiment. Microbial Ecology, 69: 395-406. 